\title{
Enerji Fiyatlarının Sanayi Sektörü Hisse Senedi Fiyatları Üzerindeki Etkisi: Borsa İstanbul Sanayi Sektörü Şirketleri
}

\author{
Murat YILDIRIM* \\ Yilmaz BAYAR** \\ Abdülkadir KAYA***
}

\section{$\ddot{O Z E T}$}

Enerji kaynakları, sanayi üretiminin başlıca girdilerinden birisini oluşturmaktadır. Bu çalışma Johansen-Juselius eşbütünleşme ve Granger nedensellik testleri ile regresyon analizini kullanarak 1991:01-2013:11 arası dönemde uluslararası ham petrol ve doğalgaz fiyatlarının Borsa İstanbul'da işlem gören sanayi şirketlerinin hisse senedi fiyatları üzerindeki etkisini incelemektedir. Çalışma sonucunda uluslararasi ham petrol ve doğalgaz fiyat endeksleri ile Borsa Istanbul sinai endeksi arasında uzun dönemli bir iliş̧ki olduğu tespit edilmiştir. Granger nedensellik testlerinin sonucunda ham petrol fiyat endeksinden sinai endeksine doğru tek yönlü nedensellik, sinai endeksinden de doğalgaz fiyat endeksine doğru tek yönlü bir nedensellik iliş̧kisi olduğu belirlenmişstir. Bununla birlikte regresyon analizi sonucunda ham petrol ve doğalgaz fiyatlarının hisse senedi fiyatlarını pozitif etkilediği tespit edilmistir.

Anahtar Kelimeler: Borsa İstanbul Sinai Endeksi, Ham Petrol Endeksi, Uluslararası Doğalgaz Fiyat Endeksi.

JEL Sinıflandirması: C58, G10, Q32.

\section{Effects of Energy Prices on Stock Prices of the Industry Sector: Borsa Istanbul Industrial Corporations}

\section{ABSTRACT}

Energy sources are one of the major inputs to the industrial production. This study examines the effects of international crude oil and natural gas prices on the industrial corporations listed on the Borsa Istanbul during the period 1991:01-2013:11 by using Johansen-Juselius cointegration test, Granger causality test and regression analysis. We found that there was a long run relationship between Borsa Istanbul industrial index, international crude oil price index and natural gas price index. A unidirectional causality from crude oil price index to industrial index and a unidirectional causality from industrial index to natural gas price index were determined as a consequence of Granger causality test. However we also found that crude oil and natural gas prices affected industrial index positively as a consequence of regression analysis.

Keywords: Borsa Istanbul Industrial Price Index, International Crude Oil Index, International Naturalgas Price Index.

Jel Classification: C58, G10, Q32.

\footnotetext{
* Yrd. Doç. Dr. Murat Yıldırım, Karabük Üniversitesi, İktisadi ve İdari Bilimler Fakültesi, muratyildirim@karabuk.edu.tr

${ }^{* *}$ Yrd. Doç. Dr. Yılmaz Bayar, Karabük Üniversitesi, İşletme Fakültesi, yilmazbayar@karabuk.edu.tr

*** Yrd. Doç. Dr. Abdülkadir Kaya, Erzurum Teknik Üniversitesi, İktisadi ve İdari Bilimler Fakültesi, akadirkaya@erzurum@edu.tr
} 


\section{GíRiş}

Enerji kaynakları, sanayi üretiminin önemli girdilerinden birisidir. Başlıca enerji kaynakları petrol, doğalgaz ve kömürün 2010 yılında toplam enerji kullanımındaki payı $\% 84$ 'tür. Toplam enerji tüketimi içerisinde petrol, kömür ve doğalgazın payları ise sırasıyla $\% 34, \% 28$ ve $\% 22$ 'dir. Dünyada sanayi sektörü, enerji tüketiminde en büyük paya sahiptir ve sanayi sektörünün 2040 yılına kadar dünya enerji tüketiminin yarısından fazlasını tüketmeye devam edeceği öngörülmektedir. Yenilenebilir enerji ve nükleer enerji yılda $\% 2.5$ artışla dünyanın en hızlı büyüyen enerji kaynakları olmasına rağmen, fosil yakıtların 2040 yılına kadar dünya enerji kullanımının yaklaşık \%80'ini karşılamaya devam etmesi beklenmektedir (EIA, 2013).

Dünya enerji gereksiniminin yaklaşık \%80'inin uzun bir süre fosil yakttlar tarafindan karşılanacağı dikkate alındığında, fosil yakıt fiyatları dünya enerji arzının yarısından fazlasını tüketen sanayi sektörü için büyük önem arz etmektedir. Dolayısıyla sanayi şirketleri için önemli bir girdi olan enerji fiyatlarındaki değişmelerin doğrudan şirketlerin karlılı̆̆ dolayısıyla da hisse senedi fiyatları üzerinde etkili olması beklenebilir.

Türkiye'nin 2012 yllında 11.6 milyar dolar, 2011 yllında ise 11.8 milyar dolar değerinde petrol ve doğalgaz ithal etmiştir (TÜiK, 2013). Sonuç olarak Türkiye petrol ve doğalgaz ihtiyacını büyük oranda ithalatla karşılamaktadır. Bundan dolayı petrol ve doğalgaz fiyatlarındaki dalgalanmalar özellikle sanayi şirketleri ve ülke ekonomisi üzerinde önemli etkiye sahiptir.

$\mathrm{Bu}$ çalışmanın amacı, uluslararası ham petrol ve doğalgaz fiyatlarının Borsa İstanbul (BİST)'da işlem gören sanayi sektörü şirketlerinin hisse senedi fiyatları üzerindeki etkilerini incelemektir. Çalışmanın ikinci bölümünde enerji fiyatlarının hisse senedi fiyatları ve getirileri üzerindeki etkilerini tespit etmeye yönelik literatürdeki çalısmalara yer verilmiştir. Üçüncü bölümde çalışmada kullanılan veri, yöntem ve uygulama hakkında bilgi verilerek, bulgular tartşsılmıştır. Son bölümde ise çalş̧mada ulaşılan baş̧ıca bulgular özetlenmiştir.

\section{LITERATÜR TARAMASI}

Petrol, doğalgaz başta olmak üzere enerji fiyatları ile hisse senedi endeksleri ve hisse senedi getirileri arasındaki ilişkiyi tespit etmek üzere çok sayıda çalışma bulunmaktadır. Bununla birlikte literatürdeki çalışmalar ağıllıklı olarak petrol fiyatlarının hisse senedi fiyatları üzerindeki etkisini tespit etmeye yöneliktir. Çalışmalar sonucunda petrol ve doğalgaz fiyatlarının hisse senedi fiyatları üzerindeki etkilerine yönelik farklı bulgulara ulaşılmıştır. Bu bölümde enerji fiyatlarının hisse senedi piyasaları üzerindeki etkilerine yönelik öncelikle Türkiye dışındaki ülkelerde yapılan çalışmalar, daha sonra ise enerji fiyatlarının Borsa İstanbul üzerindeki etkilerine yönelik yapılan çalışmalar kronolojik olarak verilecektir. 


\subsection{Enerji Fiyatlarının Yabancı Hisse Senedi Piyasaları Üzerindeki Etkilerine Yönelik Çalışmalar}

Asteriou vd. (2013) Ocak 1998-Aralık 2008 aras1 dönemde Vektör Otoregresyon (VAR) modelleri ve Granger nedensellik testi kullanarak petrol ithal eden ve petrol ihraç eden ülkelerde petrol fiyat dalgalanmalarının hisse senedi piyasaları ve faiz oranları üzerindeki etkisini incelemiş̧lerdir. Çalışmaları sonucunda petrol fiyatlarının kısa ve uzun dönemde faiz oranlarına göre daha güçlü bir şekilde hisse senedi piyasaları ile etkileşimde olduklarını, petrol fiyatlarının hisse senedi piyasaları üzerindeki etkisinin petrol ihraç eden ülkelere göre petrol ithal eden ülkelerde daha fazla olduğunu, ayrıca petrol fiyatlarındaki dalgalanmaların ülkelerin kalkınmışlık derecesine göre farklı ülkeler içerisinde farklılık gösterdiğini tespit etmişlerdir. Bir başka çalışmada Asteriou ve Bashmakova (2013) 22 Ekim 1999-23 Ağustos 2007 arası dönemde uluslararası çoklu faktör modeli kullanarak 10 Orta ve Doğu Avrupa ülkesinde petrol fiyat riski ve hisse senedi piyasası getirileri arasındaki ilişkiyi incelemişlerdir. Çalışmaları sonucunda petrol fiyatının betasının negatif ve istatistiksel olarak anlamlı olduğunu, dolayısıyla da petrol fiyatının hisse senedi getirilerinin belirlenmesinde önemli bir faktör olduğunu tespit etmişlerdir.

Acaravc1 vd. (2012) Johansen-Juselius eşbütünleşme testi ve Granger nedensellik modellerine dayalı hata düzeltme modelini kullanarak Ocak 1990-Ocak 2008 arası dönemde AB-15 ülkelerinde doğalgaz fiyatları ile hisse senedi fiyatları arasındaki uzun dönemli ilişkiyi incelemişlerdir. Çalışma sonucunda Avusturya, Danimarka, Finlandiya, Almanya ve Lüksemburg'ta doğalgaz fiyatları, sanayi üretimi ve hisse senedi fiyatları arasında uzun dönemli bir ilişki ve bu iki değişken arasında dolaylı bir Granger nedenselliği olduğu bulgusuna ulaşmışlardır. Adaramola (2012) Johansen eşbütünleşme ve Granger nedensellik testlerini kullanarak Ocak 1985-Nisan 2009 arası dönemde Nijerya'da petrol fiyatı ile hisse senedi getirileri arasındaki ilişkiyi incelemiştir. Çalışma sonucunda hisse senedi getirilerinin kısa dönemde petrol fiyat şokuna pozitif, uzun dönemde ise negatif tepki verdiklerini, petrol fiyat şokundan hisse senedi getirilerine doğru tek yönlü bir nedensellik olduğunu tespit etmiştir.

Le ve Chang (2011) Ocak 1986-Şubat 2011 arası dönemde Japonya, Singapur, Güney Kore ve Malezya'da etki tepki ve varyans ayrıştırması analizlerini kullanarak hisse senedi fiyatlarının petrol fiyatlarındaki oynaklıklara verdikleri tepkileri incelemişlerdir. Çalışmaları sonucunda hisse senedi piyasasının Japonya'da pozitif, Malezya'da ise negatif tepki verdiğini, Singapur ve Güney Kore'de ise verilen tepkinin belirsiz olduğunu tespit etmişlerdir. Oberndorfer (2009), 1 Ocak 2002-15 Ağustos 2007 arası dönemde enerji piyasasındaki gelişmelerin Euro bölgesi enerji şirketlerinin getirileri üzerindeki etkisini incelemiştir. Çalışma sonucunda petrol fiyatlarındaki artışların, petrol ve doğalgaz hisse senetlerinde değerlenmeye yol açtığını, öngörülebilir petrol piyasası oynaklığının Euro bölgesi petrol ve doğalgaz hisse senetlerini negatif olarak etkilediğini tespit etmiş, doğalgaz piyasasının Euro bölgesi enerji hisse senetlerinin fiyatlamasında bir rolü olmadığını tespit etmiştir. 
Hacıhasanoğlu ve Soytaş (2011) 10 Mayıs 2007-15 Mart 2011 arası dönemde eşbütünleşme ve nedensellik testlerini kullanarak petrol fiyatları ile S\&P 500 endeksi arasındaki ilişkiyi incelemişlerdir. Çalışma sonucunda petrol fiyatının düşme trendinde olduğu dönemde hisse senedi getirilerinden petrol getirilerine pozitif yönde ve petrol getirilerinden oynaklığa yine pozitif yönde Granger nedensellik olduğunu, petrol fiyatının arttığ1 dönemde ise petrol ve hisse senedi getirileri arasında nedensellik olmadığını, hisse senedi getirilerinden petrol piyasası oynaklı̆̆ına negatif yönde uzun dönem kalıcı etki olduğunu tespit etmişlerdir. Sayılgan ve Süslü (2011) 1996-2006 arası dönemde panel veri analizi kullanarak gelişen piyasalarda (emerging markets) makroekonomik değişkenlerin hisse senedi getirileri üzerindeki etkilerini incelemişler, çalışma sonucunda makroekonomik değişkenlerden birisini oluşturan petrol fiyatları ile hisse senedi getirileri arasında istatistiksel olarak anlamlı bir ilişki tespit etmemişlerdir.

Park ve Ratti (2008), Ocak 1986-Aralık 2005 aras1 dönemde VAR modelleri kullanarak $\mathrm{ABD}$ ve 13 Avrupa ülkesinde petrol fiyat şoklarının hisse senedi piyasaları üzerindeki etkilerini incelemişlerdir. Çalışma sonucunda petrol fiyat şoklarının ABD ve 12 petrol ithal eden Avrupa ülkesinde reel hisse senedi getirileri üzerinde negatif etkiye sahip olduğunu tespit etmişlerdir. Anoruo ve Mustafa (2007) 1993-2006 arası dönemde eşbütünleşme testi ve vektör hata düzeltme modeli (VECM)'ni kullanarak ABD'de petrol ve hisse senedi piyasası getirileri arasındaki ilişkiyi incelemişlerdir. Çalışma sonucunda hisse senedi piyasası ile petrol piyasası arasında uzun dönemli bir ilişki olduğu ve hisse senedi piyasası getirilerinden petrol piyasası getirilerine doğru tek yönlü bir nedensellik olduğunu bulgularına ulaşmışlardır.

Basher ve Sadorsky (2006) 31 Aralık 1992- 31 Ekim 2005 arası dönemde uluslararası çoklu faktör modeli kullanarak 21 gelişen ülke (emerging countries)'de petrol fiyatlarındaki değişmelerin hisse senedi getirileri üzerindeki etkilerini incelemişlerdir. Çalışmaları sonucunda petrol fiyat riskinin bu ülkelerde hisse senedi fiyat getirilerini etkilediğini, ilişkinin kısmen kullanılan verilerin frekansına bağlı olduğunu tespit etmişlerdir. Bu kapsamda günlük ve aylık veriler kullanıldığında petrol fiyat artışlarının aşırı hisse senedi piyasası getirileri üzerinde pozitif etkiye sahip olduğunu, haftalık ve aylık veriler kullanıldığında petrol fiyat düşüşlerinin hisse senedi piyasası getirileri üzerinde pozitif etkiye sahip olduğu bulgularına ulaşmışlardır.

Sadorsky (1999) 1947-1996 döneminde VAR ve Genelleştirilmiş Otoregresif Koşullu Değişen Varyans (GARCH) analizlerini kullanarak ABD'de petrol şokları ile hisse senedi piyasası, faiz oranı ve sanayi üretimi arasındaki ilişkiyi incelemiştir. Çalışma sonucunda petrol fiyatlarındaki değişmelerin ekonomik faaliyeti etkilediği, ancak ekonomik faaliyetteki değişmelerin petrol fiyatları üzerinde az etkiye sahip olduğu ve petrol fiyat hareketlerinin hisse senedi getirilerindeki hareketleri açıklamada önemli olduğu bulgularına ulaşmıştır. 


\subsection{Enerji Fiyatlarının Borsa İstanbul Üzerindeki Etkilerine Yönelik Çalışmalar}

Ergun ve Ibrahim (2013) çoklu regresyon ve etki-tepki analizini kullanarak 2005-2011 arası dönemde küresel ham petrol ve doğalgaz fiyatlarının Türkiye'de enerji şirketleri Aygaz ve Tüpraş'ın hisse senedi fiyat hareketleri üzerindeki etkisini araştırmışlardır. Çalışmaları sonucunda ham petrol ve doğalgaz fiyatlarının istikrarlı ekonomik koşullar altında enerji şirketlerinin hisse senedi fiyatları üzerinde çok sinırlı etkilerinin olduğunu tespit etmişlerdir. Güler ve Nalın (2013), 3 Şubat 1997 ile 30 Kasım 2012 tarihleri arasını kapsayan dönemde eşbütünleşme ve Granger nedensellik testlerini kullanarak petrol fiyatındaki değişim ile BİST 100, BİST Sınai ve BİST Kimya, Petrol ve Plastik endeksleri arasındaki ilişkiyi incelemişlerdir. Çalışma sonucunda petrol fiyatları ile endekslerin uzun dönemde birlikte hareket ettiklerini, ancak petrol fiyatları ile endeksler arasında bir nedensellik olmadığ bulgularına ulaşmışlardır. Öztürk vd. (2013) çalışmalarında 2 Ocak 1997-31 Aralık 2009 arası dönemde eşbütünleşme analizleri kullanarak petrol ve doğalgaz fiyatları ile İMKB imalat sektörü ve kimya-petrol-plastik sektörü endeksleri arasındaki ilişkiyi incelemişlerdir. Kırılmalı eşbütünleşme testi sonucunda petrol fiyatları ile İMKB imalat sektörü ve kimyapetrol-plastik sektörü endeksleri arasında bir eşbütünleşme ilişkisi olduğunu tespit etmişlerdir.

Ünlü ve Topçu (2012), Ocak 1990-Şubat 2001 ve Mart 2001-Aralık 2011 dönemlerinde eşbütünleşme ve nedensellik analizlerini kullanarak petrol fiyatlarının Borsa İstanbul üzerindeki etkilerini incelemişlerdir. Çalışma sonucunda birinci dönemde BİST 100 endeksi ve ham petrol fiyatları arasında eşbütünleşme ve nedensellik ilişkisi olmadığını, ancak ikinci dönemde değişkenler arasında eşbütünleşme ilişkisi olduğu ve ham petrol fiyatlarından hisse senedi piyasasına doğru tek yönlü nedensellik olduğunu tespit etmişlerdir. Berk ve Aydoğan (2012) 2 Ocak 1990-1Kasım 2011 arası dönemi üç alt döneme (2 Ocak 1990-15 Kasım 2001, 16 Kasim 2001-11 Temmuz 2008, 14 Temmuz 2008-1 Kasim 2011) bölerek VAR modeli ile Brent ham petrolü fiyatları ve küresel finansal likidite koşulları ile BİST 100 endeksi arasındaki ilişkiyi incelemişlerdir. Çalışma sonucunda küresel finansal likiditenin hisse senedi piyasası getirilerindeki değişmeleri en fazla açıkladığı, ham petrol fiyatlarının hisse senedi piyasası üzerindeki etkisinin likidite kısıtlamalarına göre göreceli alarak daha az olduğunu tespit etmişlerdir.

Kapusuzoğlu (2011), 4 Ocak 2000-4 Ocak 2010 dönemde Johansen ve Juselius eşbütünleşme ve Granger nedensellik testlerini kullanarak Borsa İstanbul Ulusal 100, 50 ve 30 endeksleri ile uluslararası Brent petrol fiyatları arasındaki uzun ve kısa dönem ilişkileri incelemiştir. Çalışma sonucunda Brent petrol fiyatları ile çalışmada kullanılan endeksler arasında uzun dönemli bir ilişki olduğunu, Brent petrol fiyatında endekslere doğru tek yönlü bir nedensellik olduğunu tespit etmiştir.

Güler vd. (2010), 10 Temmuz 2000-10 Ağustos 2009 arası dönemde eşbütünleşme ve Granger nedensellikleri testlerini kullanarak petrol fiyat değişimlerinin Borsa İstanbul'da işlem gören enerji sektörü hisse senedi fiyatları üzerindeki etkisini incelemişlerdir. Çalışma 
sonucunda Brend petrol fiyatının hisse senedi fiyatlarında ve elektrik endeksi fiyatında önemli bir gösterge olduğunu tespit etmişlerdir.

Sarı ve Soytaş (2006) 1987-2004 arası dönemde Türkiye'de ham petrol fiyat1, hisse senedi getirisi, faiz oranı ve çıktı düzeyi arasındaki ilişkiyi incelemişlerdir. Çalışmaları sonucunda petrol fiyatlarındaki şokların hisse senedi getirileri üzerinde istatistiksel olarak anlamlı bir etkiye sahip olmadığını tespit etmişlerdir.

\section{VERİ, YÖNTEM VE UYGULAMA}

\subsection{Veri}

Bu çalışmada, uluslararası ham petrol ve doğalgaz fiyatları ile BİST'de işlem gören sanayi şirketlerinin hisse senedi fiyatları arasındaki ilişki incelenmiştir. Bu etkinin tahmininde 1991:01-2013:11 zaman aralığında, dolar cinsinden ham petrol ve doğalgaz fiyatları büyüme oranı ile dolar cinsinden BİST Sınai endeksi büyüme oranı değişkenlerine ait aylık veriler kullanılmıştır. Petrol fiyatları aylık veriler halinde yayınlandığı için BİST Sınai endeksi günlük verileri aylık verilere çevrilmiştir. Uluslararası ham petrol ve doğalgaz fiyat endeksleri Uluslararası Para Fonu (IMF) veri tabanından, BİST Sınai endeksi verileri ise BİST veri tabanından elde edilmiştir. Çalışmada Eviews 7 ekonometrik analiz paket programı kullanılmıştır. Analizde kullanılan uluslararası ham petrol, doğalgaz ve BİST Sınai endekslerine ait grafikler Şekil 1, Şekil 2 ve Şekil 3'de gösterilmiştir. Analiz kullanılan verilere ilişkin bilgiler Tablo 1'de sunulmuştur.

Tablo 1: Çalışmada Kullanılan Değişkenler

\begin{tabular}{|c|c|c|c|c|}
\hline Değisşkenler & Değişkenlerin Adları & Kaynak & $\begin{array}{c}\text { Veri } \\
\text { Aralı̆̆ } \\
\end{array}$ & $\begin{array}{c}\text { Alındığı } \\
\text { Tarih } \\
\end{array}$ \\
\hline BİST & BİST Sınai Endeksi Büyüme Oranı & borsaistanbul.com & $\begin{array}{l}\text { 1991:01- } \\
\text { 2013:11 }\end{array}$ & 05.12 .2013 \\
\hline PTROL & $\begin{array}{c}\text { Ham Petrol Fiyatları Büyüme } \\
\text { Oranı }\end{array}$ & imf.org & $\begin{array}{l}\text { 1991:01- } \\
2013: 11\end{array}$ & 05.12 .2013 \\
\hline DGAZ & Doğalgaz Fiyatları Büyüme Oranı & imf.org & $\begin{array}{l}\text { 1991:01- } \\
2013: 11\end{array}$ & 05.12 .2013 \\
\hline
\end{tabular}

\subsection{Yöntem}

Çalışmada kullanılan değişkenlerin önce Phillips-Perron (1988) testleri ile birim kök sınaması yapılacaktır. Daha sonra değişkenler arasında uzun dönemli ilişkiyi tespit etmek için Johansen-Juselius eşbütünleşim testi uygulanacaktır. Değişkenler arasında uzun dönemli bir ilişkinin bulunması halinde, değişkenler arasındaki nedensellik ve nedenselliğin yönünün belirlenmesi amacıyla Granger nedensellik testi kullanılacaktır. Son olarak uluslararası ham petrol ve doğalgaz fiyatlarının sanayi sektörü şirketlerinin hisse senedi fiyatları üzerindeki etkisinin derecesini ve yönünü belirlemek amacıyla regresyon analizi yapılacaktır. 


\subsection{Ampirik Uygulama ve Sonuçları}

Analizlerde kullanılacak değişkenler zaman serisi olduğu için, verilerin durağan olmasını gerekmektedir. Durağan olmayan zaman serileriyle çalışılması sahte regresyon problemine yol açmaktadır. Bu durumda regresyon analizinden elde edilen sonuçlar gerçek ilişkiyi yansıtmamaktadır (Gujarati, 1999:726). Çalışmada öncelikli olarak, değişkenlerin durağan olup olmadıkları ve durağanlık seviyeleri Phillip-Perron birim kök testi ile sınanmıştır. BİST, PTROL ve DGAZ değişkenlerine ait birim kök testi sonuçları, sabitli ve sabitli-trendli olarak belirlenmiş Tablo 2'de sunulmuştur. Birim kök testi sonuçları incelendiğinde BİST, PTROL ve DGAZ değişkenlerinin seviye değerinde durağan olduğu tespit edilmiştir.

Tablo 2: Phillip Perron Birim Kök Test Sınaması Sonuçları

\begin{tabular}{|c|c|c|}
\hline \multirow{2}{*}{ Değişkenler } & \multicolumn{2}{|c|}{ Seviye Değeri } \\
\hline & Sabitli & Sabitli ve Trendli \\
\hline BİST & $-12,652^{a}$ & $-12,624^{a}$ \\
\hline PTROL & $-13,045^{a}$ & $-13,080^{a}$ \\
\hline DGAZ & $-16,573^{a}$ & $-16,548^{a}$ \\
\hline Kritik Değerler & & \\
\hline$a=\%$ & $-3,454$ & $-3,991$ \\
\hline$b=\% 5$ & $-2,871$ & $-3,426$ \\
\hline$c=\% 10$ & $-2,572$ & $-3,136$ \\
\hline
\end{tabular}

$\mathrm{a}=\% 1$ önem düzeyinde anlamlılı̆̆ göstermektedir.

BİST, PTROL ve DGAZ değişkenleri arasındaki uzun dönemli ilişkinin belirlenmesi için eş bütünleşme sınaması yapılmıştır. Çalışmada bu amaçla Johansen-Juselius eşbütünleşme testi kullanılmıştır. Bu metotta serinin bir başka seri ile eşbütünleşik olup olmadığının sınanması için parametrenin öz değerinden yararlanılmıştır. Bu amaçla birinci dereceden bir vektör otoregresif zaman serisi aşağıdaki gibi verilmiş olsun.

$$
Y=A Y_{\sim t-1}+e_{\sim t} \quad(t=1,2,3, \ldots, n)
$$

(1) nolu eşitlikte A matrisi $\mathrm{k}$ boyutlu parametre matrisi olmak üzere $e_{\star t}$ 'ler varyans kovaryans matrisi $\mathrm{V}$ olan beyaz gürültü sürecini göstermektedir. $\Pi=A-I$ olmak üzere, $\Pi$ matrisinin rankı sıfır ise seri eşbütünleşik değildir. Buradaki Johansen testi iz istatistiği (trace statistics) olarak da adlandırılan olabilirlik oranına (Likelihood Ratio) dayandırılır. Tablo 3, BİST, PTROL ve DGAZ değişkenlerine ait Johansen Juselius eş bütünleşik testi sonuçlarını göstermektedir. Tablo incelendiğinde, BİST ile PTROL ve BİST ile DGAZ değişkenleri arasında eş bütünleşmenin olmadığını gösteren $\mathrm{H}_{\mathrm{o}}$ hipotezinin reddedildiği görülmektedir. 
Buna göre, BİST ile PTROL ve BİST ile DGAZ değişkenleri eş bütünleşiktir, yani BİST değişkeni ile hem PTROL hem de DGAZ değişkenleri arasında uzun dönemli bir ilişki bulunmaktadır.

Diğer taraftan, değiş̧kenler arasında bir eşbütünleşme söz konusu ise, bunlar arasında en az tek yönlü bir iktisadi nedensellik ilişkisi olma ihtimali vardır (Gujarati, 1999: 623). Bu durumda eşbütünleşik değişkenler arasında bir nedensellik sınaması gündeme gelecektir.

Tablo 3: Johansen Juselius Eş Bütünleşme Test Sonuçları

\begin{tabular}{|c|c|c|c|c|c|}
\hline \multirow{2}{*}{ Değişken Çifti } & \multicolumn{2}{|c|}{ Hipotezler } & \multirow{2}{*}{ İz İstatistiği } & \multirow{2}{*}{$\begin{array}{c}\text { \%1 Kritik } \\
\text { Değer }\end{array}$} & \multirow{2}{*}{$\begin{array}{c}\text { \%5 Kritik } \\
\text { Değer }\end{array}$} \\
\hline & $\mathbf{H}_{\mathbf{0}}$ & $\mathbf{H}_{1}$ & & & \\
\hline BİST & $\mathrm{r}=\mathrm{o}$ & $\mathrm{r}=1$ & $119,07^{\mathrm{a}}$ & 16,361 & 12,320 \\
\hline PTROL & $r \leq 1$ & $r=2$ & $0,154^{\mathrm{a}}$ & 6,940 & 4,129 \\
\hline BİST & $\mathrm{r}=\mathrm{o}$ & $\mathrm{r}=1$ & $96,35^{\mathrm{a}}$ & 16,361 & 12,320 \\
\hline DGAZ & $\mathrm{r} \leq 1$ & $r=2$ & $24,815^{\mathrm{a}}$ & 6,940 & 4,129 \\
\hline
\end{tabular}

$\mathrm{a}=\% 1$ önem düzeyinde anlamlılı̆̆ göstermektedir.

Çalışmada değişkenler arasındaki nedensellik ilişkisi Granger nedensellik testi kullanılarak yapılmıştır. Varsayım gereği sıfır veya boş hipotezimizin reddi şeklindeki alternatif hipotez, değişkenler arasında nedensel bir ilişkinin varlığını gösterecektir.

İlk kez Granger (1969) tarafından literatüre kazandırılmış olan Granger Nedensellik Sınaması daha sonra Hamilton (1994) tarafından geliştirilmiştir. Granger nedenselliğinde $\mathrm{x}$ ve y gibi iki değişken arasındaki ilişkinin yönü araştırıllı. Şayet mevcut y değeri, $\mathrm{x}$ değişkeninin şimdiki değerinden çok, geçmiş değerleri ile daha iyi tahmin edilebiliyorsa, $x$ değişkeninden y değişkenine doğru Granger nedenselliğinin varlığından bahsedilir (Charemza vd., 1993:190). Granger Nedensellik Testi’ aşağıdaki iki denklem yardımıyla yapılmaktadır.

$$
\begin{aligned}
& Y_{t}=\alpha_{0}+\sum_{i=1}^{k 1} \alpha_{i} Y_{t-i}+\sum_{i=1}^{k 2} \beta_{i} X_{t-i}+\varepsilon_{t} \\
& X_{t}=\chi_{0}+\sum_{i=1}^{k 3} \chi_{i} X_{t-i}+\sum_{i=1}^{k 4} \delta_{i} Y_{t-i}+v_{t}
\end{aligned}
$$

Granger nedensellik analizi, yukarıdaki modellerde hata teriminden önce yer alan bağımsız değişkenin gecikmeli değerlerinin katsayılarının grup halinde sıfira eşit olup olmadığı test edilerek yapılır. (2) nolu denklemdeki $\beta_{i}$ katsayıları belirli bir anlamlılık düzeyinde sıfirdan farklı bulunursa, X'in Y'nin nedeni olduğu sonucuna varılır. Aynı şekilde (3) nolu denklemde $\delta_{\mathrm{i}}$ katsayılarının belirli bir anlamlılık düzeyinde sıfırdan farklı olması da Y'nin X'in nedeni olduğunun göstergesidir. Bu durumda Y ile X arasında karşılıklı bir 
nedensellik ilişkisi var demektir. Sadece (2) nolu denklemdeki $\beta_{\mathrm{i}}$ katsayıları sıfırdan farklı ise X'den Y'ye doğru tek yönlü, sadece (3) nolu denklemdeki $\delta_{i}$ katsayıları sıfırdan farklı ise Y'den X'e doğru tek yönlü nedensellik vardır. Hem $\beta_{i}$ hem de $\delta_{\mathrm{i}}$ katsayılarının sıfırdan farklı olmaması durumunda ise iki değişken arasında herhangi bir nedensellik ilişkisi yoktur.

Granger nedensellik testi şu şekilde yapılmaktadır. Öncelikle bağımlı değişken kendi gecikmeli değerleri ile regresyona tabi tutularak Akaike Bilgi Kriteri veya Phillip Perron Bilgi Kriteri minimum yapan gecikme uzunluğu uygun gecikme uzunluğu olarak tespit edilir. Bağımlı değişken uygun gecikme uzunluğu ile modele dahil edildikten sonra, modele girecek ikinci değişkenin olası tüm gecikmeleri ile birlikte oluşan tüm regresyon modellerinin Akaike Bilgi Kriteri veya Phillip Perron Bilgi Kriteri değerleri elde edilmekte ve en küçük bilgi kriterine sahip olan modeldeki ikinci değişkenin gecikme sayısı, modele ikinci sırada giren değişkenin en uygun gecikme sayısı olarak tespit edilmektedir (Kadılar, 2000: 54). BİST ile PTROL ve DGAZ değişkenlerinin 0'dan 6'ya kadar gecikmeli değerleri ile oluşturulan regresyon modeline ait Akaike ve Phillip Perron Bilgi Kriterlerina ait değerleri Tablo 4'de sunulmuştur. Tablo 4 incelendiğinde en küçük bilgi kriterlerinin olduğu gecikme uzunluğunun BİST ile PTROL değişkenleri için 2, BİST ile DGAZ değişkenleri için 6 olduğu tespit edilmiştir.

Tablo 4: Akaike ve Phillip Perron Bilgi Kriterleri

\begin{tabular}{|c|c|c|c|c|}
\hline \multirow{2}{*}{$\begin{array}{c}\text { Gecikme } \\
\text { Uzunluğu }\end{array}$} & \multicolumn{2}{|c|}{ BİST - PTROL } & \multicolumn{2}{c|}{ BISST - DGAZ } \\
\cline { 2 - 5 } & Kriteri & $\begin{array}{c}\text { Phillip Perron } \\
\text { Bilgi Kriteri }\end{array}$ & $\begin{array}{c}\text { Akaike Bilgi } \\
\text { Kriteri }\end{array}$ & $\begin{array}{c}\text { Phillip Perron } \\
\text { Bilgi Kriteri }\end{array}$ \\
\hline $\mathbf{0}$ & $-3,70$ & 8,48 & $-4,06$ & 5,90 \\
\hline 1 & $-3,79$ & 7,76 & $-4,11$ & 5,59 \\
\hline 2 & $-\mathbf{3 , 8 0}$ & $\mathbf{7 , 6 5}$ & $-4,10$ & 5,64 \\
\hline 3 & $-3,78$ & 7,80 & $-4,41$ & 4,13 \\
\hline 4 & $-3,79$ & 7,78 & $-4,41$ & 4,15 \\
\hline 5 & $-3,78$ & 7,84 & $-4,42$ & 4,10 \\
\hline 6 & $-3,77$ & 7,89 & $-4,69$ & 3,93 \\
\hline
\end{tabular}

BİST ile PTROL ve BİST ile DGAZ değişkenleri aralarındaki nedenselliğin varlığı ve nedenselliğin yönünü gösteren Granger Nedensellik Testi sonuçları Tablo 5'de sunulmuştur. Tabloya göre, BİST ile PTROL değişkenleri arasında, BİST değişkeninden PTROL değişkenine doğru bir nedenselliğin olmadığ fakat PTROL değişkeninden BİST değişkenine doğru bir nedensellik ilişkisinin varlığı tespit edilmiştir. BIST ile DGAZ değişkenleri arasında ise DGAZ değişkeninden BİST değişkenine doğru bir nedensellik bulunmamaktayken, BİST değişkeninden DGAZ değişkenine doğru bir nedensellik olduğu belirlenmiştir. Bu sonuca göre petrol fiyatlarındaki değişimlerin, hisse senedi fiyatları üzerinde etkisinin bulunduğunu, 
hisse senedi fiyatlarındaki değişimlerin ise doğalgaz fiyatları üzerinde etkisi olduğunu söyleyebiliriz.

Tablo 5: Granger Nedensellik Testi Sonuçları

\begin{tabular}{|c|c|c|c|}
\hline Değişkenler & Nedenselliğin Yönü & F İstatistiği & Olasılık \\
\hline PTROL - BİST & $\Rightarrow$ & $3,856^{\mathrm{b}}$ & 0,02 \\
BİST - PTROL & - & 1,222 & 0,29 \\
\hline DGAZ - BİST & - & 1,403 & 0,21 \\
BİST - DGAZ & $\Rightarrow$ & $3,075^{\mathrm{a}}$ & 0,00 \\
\hline
\end{tabular}

$\mathrm{a}=\% 1, \mathrm{~b}=\% 5$ önem düzeyinde anlamlılığ 1 göstermektedir.

BİST ve PTROL değişkenleri arasındaki ilişkinin derecesini ve yönünü belirlemek amacıyla 4 numaralı model oluşturulmuş ve En Küçük Kareler (EKK) yöntemiyle regresyon analizi yapılmıştır. Regresyon analizi aralarında sebep-sonuç ilişkisi bulunan iki veya daha fazla değişken arasındaki ilişkiyi belirlemek ve bu ilişkiyi kullanarak o konu ile ilgili tahminler ya da kestirimler yapabilmek için geliştirilmiş istatistiksel bir yöntemdir. $\mathrm{Bu}$ yöntemde iki veya daha fazla değişken arasındaki ilişkiyi açıklamak amacıyla matematiksel bir model kurulur ve bu model regresyon modeli olarak adlandırılır (Alma ve Vupa; 2008:220).

Regresyon analizi bağımlı veya açıklanan değişken (Y) ile bağımsız veya açıklayıcı değişken (X ya da X'ler) arasındaki ilişkiyi tanımlama ve bu ilişkinin derecesini hesaplayan araçlardan biridir (Tarı; 1999; 15).

$$
B \dot{I S T}=\alpha+\beta P T R O L+\beta_{1} D G A Z+u
$$

BİST ile PTROL ve DGAZ değişkenleri ile oluşturulan 4 numaralı regresyon modelinin tahmin sonuçları Tablo 6'da sunulmuştur. Tablo 6'ya göre, oluşturulan model ile PTROL ve DGAZ değişkenleri istatistiksel olarak \%5 önem düzeyinde anlamlı bulunmuştur. Sonuçlara göre, petrol fiyatları ve doğalgaz fiyatları ile hisse senedi fiyatları arasında pozitif bir etkileşimin olduğu belirlenmiştir.

Tablo 6: BİST ile PTROL ve DGAZ Arasındaki EKK Tahminleri

\begin{tabular}{|l|c|c|c|c|}
\hline Bağımsız Değişkenler & Katsayı & $\begin{array}{c}\text { Standart } \\
\text { Sapma }\end{array}$ & $\begin{array}{c}\boldsymbol{t} \\
\text { İstatistiği }\end{array}$ & Anlamıılık \\
\hline C (Sabit Terim) & $\mathbf{0 , 0 0 8 6}$ & $\mathbf{0 , 0 0 7 5}$ & $\mathbf{1 , 1 5 0 4}$ & $\mathbf{0 , 2 5 1}$ \\
\hline PTROL & $\mathbf{0 , 1 9 6 8}$ & $\mathbf{0 , 0 9 6 4}$ & $\mathbf{2 , 0 4 1 2}$ & $\mathbf{0 , 0 4 2}$ \\
\hline DGAZ & $\mathbf{0 , 1 9 4 0}$ & $\mathbf{0 , 1 1 4 8}$ & $\mathbf{1 , 6 8 9 5}$ & $\mathbf{0 , 0 9 2}$ \\
\hline \hline R-squared & 0,024 & \multicolumn{2}{|c|}{ F-statistic } & 3,375 \\
\hline Durbin-Watson stat & 1,520 & \multicolumn{2}{|c|}{ Prob (F-statistic) } & 0,035 \\
\hline
\end{tabular}




\section{SONUÇ VE ÖNERILER}

$\mathrm{Bu}$ çalışmada, Johansen-Juselius eşbütünleşme testi, Granger nedensellik testi ve regresyon analizi kullanılarak 1991:01-2013:11 dönemi için uluslararası ham petrol ve doğalgaz fiyatlarının, Borsa İstanbul'da işlem gören sanayi şirketlerinin hisse senedi fiyatları üzerindeki etkileri incelenmiştir. Eşbütünleşme testi sonucunda uluslararası ham petrol fiyatları ve doğalgaz fiyatları ile Borsa İstanbul sınai endeksi arasında uzun dönemli bir ilişkinin olduğu belirlenmiştir. Daha sonra nedenselliğin yönünü belirlemek amaciyla uygulanan Granger nedensellik testi sonucunda petrol fiyatlarından BİST Sinai endeksine doğru ve BİST sınai endeksinden doğalgaz fiyatlarına doğru tek yönlü nedensellik olduğu tespit edilmiştir. Son olarak değişkenler arasındaki ilişkinin derecesini belirlemek amacıyla yapılan regresyon analizi sonucunda uluslararası ham petrol fiyatları ve doğalgaz fiyatlarının hisse senedi fiyatlarını pozitif yönde etkilediği sonucuna varılmıştır.

Rezervleri sınırlı olan petrol ve doğalgaz fiyatlarındaki yükselme ağırlıklı olarak bu kaynakların toplam talebindeki artıştan kaynaklanmaktadır. Petrol talebine artış, petrolü girdi olarak kullanan sanayi sektörü ürünlerine talepteki artışı da yansıtmaktadır. Petrol fiyatlarında yaşanan artışa rağmen sanayi mallarına talebin güçlü olması uzun dönemde şirketlerin karlılıklarını artırarak hisse senedi fiyatlarında artışa neden olduğu değerlendirilmektedir.

Diğer yandan doğalgaz, petrol ve kömüre göre dünyada göreceli olarak daha az kullanılmaktadır. Buna karşın Türkiye'de ve dünyada doğalgaz ağırlıklı olarak sanayi sektöründe kullanılması ve dünyada doğalgaz kullanımının yaygınlaşması doğalgaz fiyatlarının artmasına neden olmaktadır.

\section{KAYNAKLAR}

Acaravci, A., Ozturk, I. ve Kandir, S.Y. (2012), "Natural Gas Prices and Stock Prices: Evidence from EU-15 Countries", Economic Modelling, Vol.29, s.1646-1654.

Adaramola, A.O. (2012), "Oil Price Shocks and Stock Market Behaviour: The Nigerian Experience", Journal of Economics, Vol.3, No.1, s.19-24.

Alma, Ö. G ve Vupa, Ö. (2008) Regresyon Analizinde Kullanılan En Küçük Kareler ve En Küçük Medyan Kareler Yöntemlerinin Karşılaştırılması SDÜ Fen Edebiyat Fakültesi Fen Dergisi (E-Dergi), Cilt:3, No:2, 219-229.

Anoruo, E. ve Mustafa, M. (2007), “An Empirical Investigation into the Relation of Oil to Stock Markets Prices", North American Journal of Finance and Banking Research, Vol.1, No.1, ss.22-36.

Asteriou, D., Dimitras, A. ve Lendewig, A. (2013), "The Influence of Oil Prices on Stock Market Returns: Empirical Evidence from Oil Exporting and Oil Importing Countries", International Journal of Business and Management, Vol.8, No.18, s.101120. 
Asteriou, D. ve Bashmakova, Y. (2013), “Assessing the Impact of Oil Returns on Emerging Stock Markets: A Panel Data Approach for ten Central and Eastern European Countries", Energy Economics, Vol.38, s.204-211.

Basher, S.A., Sadorsky, P. (2006), "Oil Price Risk and Emerging Stock Markets", Global Finance Journal, Vol.17, s.224-251.

Berk, I. ve Aydogan, B. (2012), "Crude Oil Price Shocks and Stock Returns: Evidence from Turkish Stock Market under Global Liquidity Conditions", Institute of Energy Economics Institute of Energy Economics Working Paper No.12/15.

Ergun, U. ve Ibrahim, A. (2013), "Global Energy Prices and the Behavior of Energy Stock Price Fluctuations", Asian Economic and Financial Review, Vol.3, No.11, s.14601465.

Granger, C.W.J. (1969) Investigating Causal Relations by Econometric Models and CrossSpectral Methods, Econometrica, Vol.37, No.3, 424-438.

Gujarati, D. N. (1999) Temel Ekonometri (Çev. Ümit Şenesen, Gülay G. Şenesen), Literatür Yayınc1lı, İstanbul.

Güler, S. ve Temel-Nalın, H. (2013), "Petrol Fiyatlarını İMKB Endeksleri Üzerindeki Etkisi”, Ekonomik ve Sosyal Araştırmalar Dergisi ,Cilt.9, Sayı.2, ss.79-97.

Güler, S., Tunç, R. ve Orçun, Ç. (2010), "Petrol Fiyat Riski ve Hisse Senedi Fiyatları Arasındaki İlişkinin Belirlenmesi: Türkiye'de Enerji Sektörü Üzerinde Bir Uygulama”, Atatürk Üniversitesi İktisadi ve İdari Bilimler Dergisi, 24(4), s.297-315.

Hacıhasanoğlu, E. ve Soytaş, U. (2011), "Emtia Fiyatları ile Hisse Senedi Piyasaları Arasındaki İlişki”, İşletme Fakültesi Dergisi, 12(1), s.53-65

Hamilton, J. D. (1994) Time Series Analysis New Jersey: Prenceton University Press.

Energy Information Administration (2013), International Energy Outlook 2013, Washington:

U.S. Energy Information Administration.

Johansen S. ve Juselius K. (1988) Hypothesis Testing for Cointegration Vectors: with Application to the Demand for Money in Denmark and Finland Discussion Papers University of Copenhagen. Department of Economics, 88-05.

Kadılar, C. (2000) Uygulamalı Çok Değişkenli Zaman Serileri Analizi, Bizim Büro Basımevi, Ankara.

Kapusuzoğlu, A. (2011), "Relationships between Oil Price and Stock Market: An Empirical Analysis from Istanbul Stock Exchange (ISE) ", International Journal of Economics and Finance, Vol.3, No.6, s.99-106.

Le, T.H. ve Chang, Y. (2011), "The Impact of Oil Price Fluctuations on Stock Markets in Developed and Emerging Economies”, Singapore Economic Review Conference. 
Oberndorfer, U. (2009), "Energy Prices, Volatility, and the Stock Market: Evidence from the Eurozone”, Energy Policy, Vol.37, s.5787-5795.

Öztürk, M.B., Gümüş, G.K., Taşkın, F.D. ve Çağlı, E.Ç. (2013), "Petrol ve Doğalgaz Fiyatları ile İmalat ve Kimya-Petrol-Plastik Sektörlerinin Endeksleri arasındaki İlişki”, Niğde Üniversitesi İİBF Dergisi ,6(2), s.64-74.

Park, J.W. ve Ratti, R.A. (2008), “Oil Price Shocks and Stock Markets in the U.S. and 13 European Countries”, Energy Economics, Vol.30, s.2587-2608.

Phillips, P.C.B. ve Perron, P. (1988), Testing for a Unit Root in Time Series Regression, Biometrika, Vol.75, s.335-346.

Sadorsky, P. (1999), "Oil Price Shocks and Stock Market Activity", Energy Economic, Vol.21, s.449-469.

Sayılgan, G. ve Süslü, C. (2011), "Makroekonomik Faktörlerin Hisse Senedi Getirilerine Etkisi: Türkiye ve Gelişmekte Olan Piyasalar Üzerine Bir İnceleme”, BDDK Bankacılık ve Finansal Piyasalar, 5(1), ss.73-96.

Tarı, R. (1999) Ekonometri Alfa Basım, Yayım Dağıtım, İstanbul.

Sari, R. ve Soytas, U. (2006) "The Relationship between Stock Returns, Crude Oil Prices, Interest Rates and Output: Evidence from a Developing Economy", The Empirical Economics Letters, 5 (4), ss.205-220.

Türkiye İstatistik Kurumu (2013), Diş Ticaret İstatistikleri, http://www.tuik.gov.tr/PreTablo.do?alt_id=1046 (21.12.2013)

Ünlü, U. ve Topçu, M. (2012), "Do Oil Prices Directly Affect Stock Markets: Evidence from Istanbul Stock Exchange”, İktisat, İşletme ve Finans, Cilt.27, Say1.319, s.75-88.

BIST (2013), Endeks Verileri, http://borsaistanbul.com/endeksler/endeks-verileri(10.12.2013)

IMF (2013), IMF Primary Commodity Prices, http://www.imf.org/external/np/res/commod/ index.aspx (10.12.2013) 


\section{EKLER}

Şekil 1: 1991:01 - 2013:11 Dönemi Uluslararası Ham Petrol Fiyat Endeksi (Dolar)

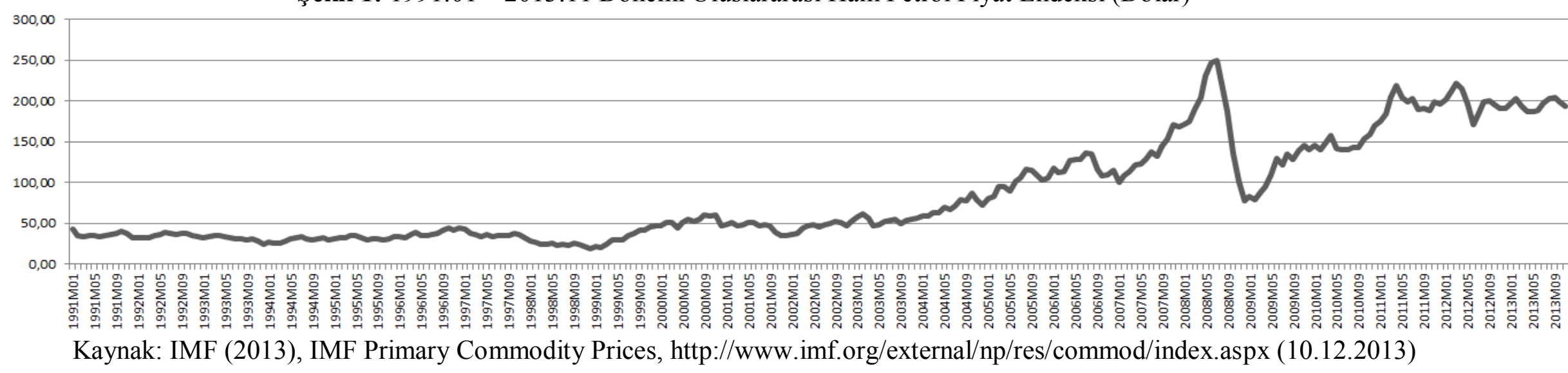

Şekil 2: 1991:01 - 2013:11 Dönemi Uluslararası Doğal Gaz Fiyat Endeksi (Dolar)

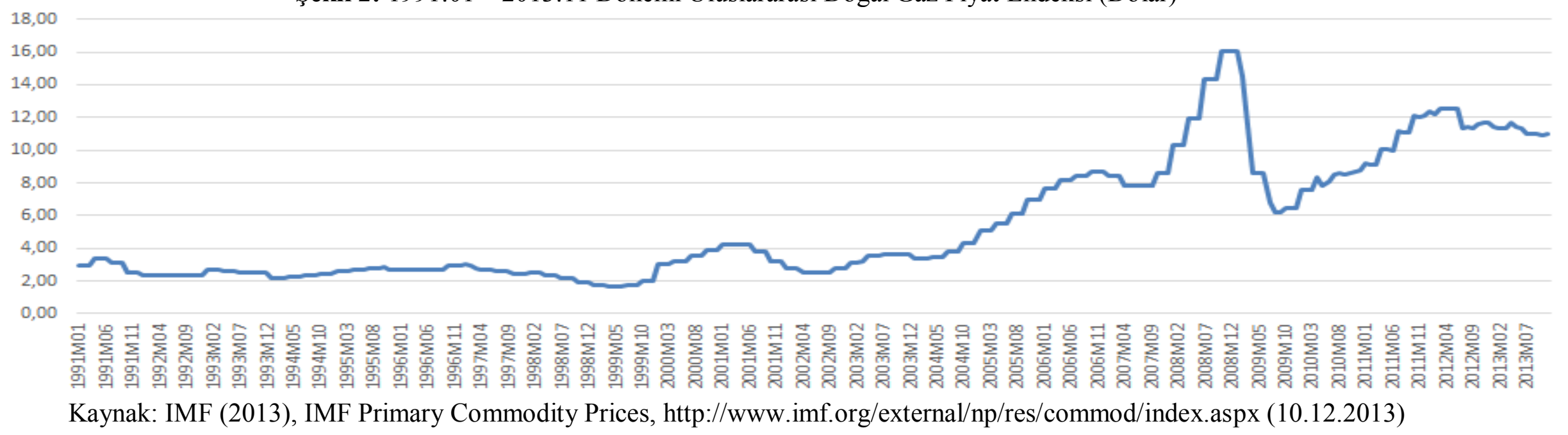




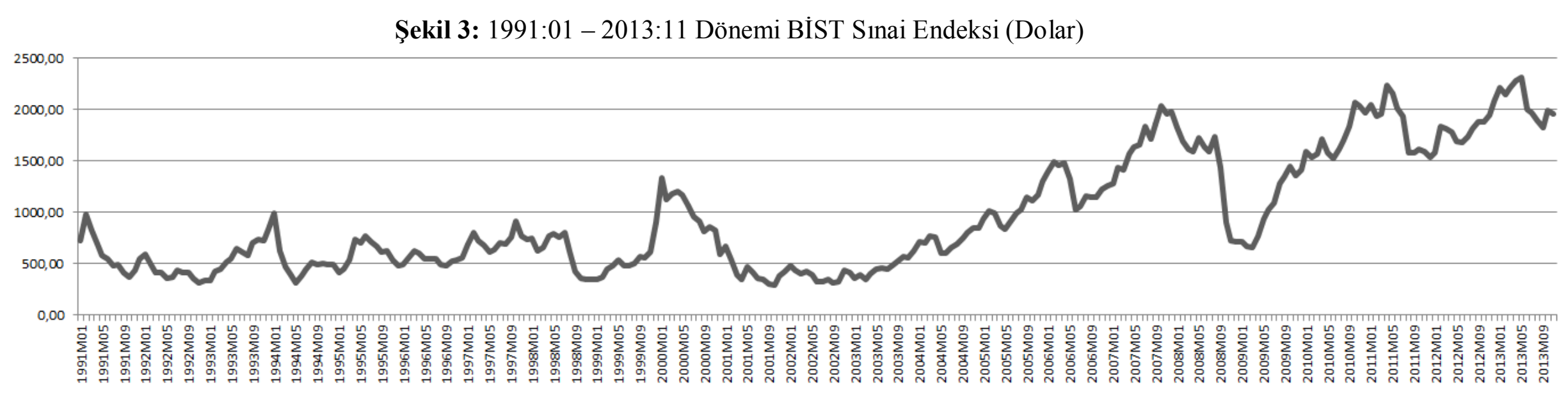

Kaynak: http://borsaistanbul.com/endeksler/endeks-verileri 
